\title{
Comparative Biochemical Studies on Indian Sedges Cyperus scar- iosus R.Br and Cyperus rotundus L.
}

\author{
Lavanya Kakarla, Rajath Othayoth and Mahendran Botlagunta*
}

\section{Lavanya Kakarla, Rajath Othayoth and Mahendran Botlagunta*}

Biomedical Research Laboratory, Department of Biotechnology, KLEF University, Vaddeswaram,

Guntur-522502, Andhra Pradesh, INDIA.

\section{Correspondence}

Dr. Mahendran Botlagunta, Biomedical Research Laboratory, Department of Biotechnology, K L E F University Vaddeswaram, Guntur - 522 502, Andhra Pradesh, INDIA.

Email: bmnchowdary@gmail.com DOI : 10.5530/pj.2016.6.14

Article Available online

http://www.phcogj.com/v8/i6

Copyright

(C) 2016 Phcog.Net. This is an openaccess article distributed under the terms of the Creative Commons Attribution 4.0 International license.

\begin{abstract}
Background: Cyperus scariosus $\mathrm{R} . \mathrm{Br}$ and Cyperus rotundus $\mathrm{L}$ are well known Indian medicinal plants in ayurveda and herbal industry. These two species are often treated as synonymous to each other, although they grow in different agro climatic conditions. Objective: In the present study, we made an attempt on comparative biochemical studies among these two species by using various spectroscopic, analytical and in silico molecular docking studies. Materials and Methods: Rhizome methanolic extracts of both the species were subjected to GC-MS and elemental analysis to identify the presence of phytochemical constituents and trace elements respectively. Following confirmation, the identified compounds were subjected to molecular docking analysis using anti-inflammatory protein COX-2 as the target receptor. Further these extracts were encapsulated into biodegradable chitosan nanoparticles and they were characterised using SEM and FT-IR analysis. Finally, the antioxidant and anti-inflammatory activity of these extract loaded nanoparticles were evaluated using in vitro assays. Results: Compounds present in both plant extracts form strong hydrogen bond interactions with COX-2. SEM analysis of $C$. scariosus showed chitosan nanoparticles are spherical in shape. Whereas $C$. rotundus forms aggregates, although they are well-dispersed in water following lyophilisation. FT-IR analysis showed that both plant extracts have different compounds, which is evident from the wavelength difference and their shift pattern as compared to blank nanoparticles. In spite of the differences, both of the drug encapsulated plant extracts showed good antioxidant and anti-inflammatory properties. Conclusion: C. scariosus and $C$. rotundus are different, but similar with some of the phytochemical constituents and pharmaceutical values.

Key words: GC-MS (Gas chromatography and Mass Spectroscopy), SEM (Scanning Electron Microscopy), EDAX (Energy Dispersive X-ray Analysis) and COX-2 (Cyclooxygenase-2).
\end{abstract}

\section{INTRODUCTION}

Medicinal plants have been used as a primary source of therapeutic agents for the prevention of diseases from minor ailments to most serious diseases. ${ }^{1}$ The search for eternal health, longevity and for remedies to relieve pain, which led to the use of plants, animal products, minerals etc., leading to the development of a variety of therapeutic agents. ${ }^{2}$ Many people now use herbal products every day, to maintain good health, as well as to treat illness. ${ }^{3}$ Historically, all pharmaceutical preparations are derived from plants, whether in the form of raw plant materials or in the refined form of crude extracts, mixtures, etc. ${ }^{4}$ Products derived from these medicinal plants exhibited a wide range of biological activities such as analgesics, antipyretics, anti-convulsants, antiinflammatory, immune modulatory, cardio protective, antihypertensive, anticoagulant, skin and bone healing agents. ${ }^{5}$ In recent years search for new pharmacologically active agents from plant extracts led to the discovery of clinically useful drugs that play a major role in the treatment of human diseases. ${ }^{6}$ There is growing interest worldwide in discovering the untapped potential of medicinal plants. Increasing demand for herbal medicine leads to depletion of natural resources. This ultimately results in use of substandard materials and adulteration. Adulteration and substitution are more frequent in raw material trade of medicine. These are common malpractices in herbal industry. At present the adulteration and substitution of herbal drugs is major serious problem in herbal industry. Adulteration is an addition of foreign substances to enhance the weight of the product. It may be due to confusion in synonyms, lack of knowledge about taxonomy of species, non availability in those particular seasons, morphological similarities, activity, aroma, careless collection and other unknown reasons. ${ }^{7}$ In India, some of the medicinal plants adultered with different species within the same family like seeds of Strychnos species, fruits and rhizomes of Piper, Ocimum, 
Datura species, Rhizomes of Chlorophytum and Cyperus species. ${ }^{8}$ To prevent adulteration and maintain the quality and efficacy of the product from Indian medicinal flora, we have chosen the medicinal plants Cyperus scariosus $\mathrm{R}$. Br and Cyperus rotundus $\mathrm{L}$ for our study.

Cyperus scariosus $\mathrm{R} . \mathrm{Br}$ and Cyperus rotundus $\mathrm{L}$ belongs to Cyperaceae family, which are well reputed plants in the traditional systems of medicine. Although they grow in different agro-climatic conditions. The taxonomists were indiscriminately classified that $C$. rotundus as C. scariosus and vice versa, they are often considered to be synonymous with each other. ${ }^{9}$ To control the adulteration and maintain the quality and efficacy of the products analytical tools play a major role in drug discovery. Keeping this in mind, in the present study, we made an attempt on comparative biochemical studies of both the plant species C. scariosus and C. rotundus through Gas chromatography mass spectrometry (GC-MS), spectroscopic techniques SEM, SEM-EDAX, FTIR and in vitro antioxidant and anti-inflammatory assays.

\section{MATERIAL AND METHODS}

\section{Collection of Plant Materials}

Cyperus scariosus $\mathrm{R} . \mathrm{Br}$ and Cyperus rotundus $\mathrm{L}$ plants were collected from the botanical garden at K L E F University campus, Vaddeswaram, Andhra Pradesh, India. For the identification and characterization of medicinally important compounds, rhizomes were separated from the plant, washed with running tap water to remove the dust, shade dried and made into fine powder with a blender. The air dried and finely crushed rhizomes of these plants were exhaustly extracted with methanol under reflux in a round bottom flask by using soxhlet apparatus. The methanolic extract was concentrated by using distillation apparatus and finally the concentrated extract poured into benzene with constant stirring, dark brown benzene soluble solution (fraction-1) and a light brown residue (fraction-2) were obtained, which were separated by filtration. The light brown residue fraction-2 was soluble in methanol were used for further experimental analysis.

\section{Isolation and identification of phytochemical compounds from C. scariosus and C. rotundus}

TLC analysis was carried to isolate the compounds. For the TLC analysis, $25 \mu \mathrm{l}$ of the each plant methanolic extract was loaded on the TLC (Silica gel 60) plates (Merck, Germany). The solvent ratio used for the separation of the compounds was ethyl acetate: methanol (1:1, v: v). Following separation, sheets were air dried and visualized under UV light alone and in the presence of iodine vapors (kept in a chamber containing concentrated iodine for 10-15 sec). Compound spots were marked, scrapped and collected separately from the silica gel and eluted in methanol (HPLC grade, Merck, India). Trace amount of silica was removed by centrifugation at 10,000 rpm. Clear supernatant was then dried aseptically and used for experimental analysis.

\section{Energy dispersive $X$-ray spectroscopy}

To evaluate elemental composition in partially purified methanolic extracts of both species we performed SEM-EDAX analysis as per the method. ${ }^{10}$ Methanolic extracts derived from plant samples of C. scariosus (CSRME) and C. rotundus (CRRME) were placed on the sample holder (Stub) with carbon tap then make a conducting layer of gold palladium with portable SC 7620 mini sputter coater/ glow discharge system (Quorum Technologies Ltd), then we load the sample in FESEM (Carl Zeiss Supra 55 GEMIN German Technology) sample holding vaccum chamber. Full screen, window and spot modes were employed depending on the size of the plant part/component. There after applying the acceleration voltage of $20 \mathrm{KV}$, working distance signal $\mathrm{A}=$ in lens is a dedectors and Mag= magnification of the image.

\section{Gas chromatography and mass spectroscopy conditions}

To identify the presence of volatile phytochemicals and to compare their occurrence in the two species methanolic extracts of the C. scariosus and C. rotundus were subjected to gas chromatography- mass spectrometry analysis as per the method. ${ }^{11}$ The phytochemicals were analyzed by GC-MS Agilent 5975-C Series instrument employing the electron impact mode (ionizing potential $-70 \mathrm{eV}$ ) and a capillary column (DB-5 ms Agilent) (length $30 \mathrm{~m} \times$ diameter $0.25 \mathrm{~mm}$, film thickness $0.25 \mu \mathrm{m}$ ) packed with $5 \%$ phenyl dimethyl silicone) and the ion source temperature was monitored at $200^{\circ} \mathrm{C}$. Further, the GC-MS settings were indicated as the initial column temperature was set at $70^{\circ} \mathrm{C}$ and kept hold for $3 \mathrm{~min}$; the temperature was increased to $300^{\circ} \mathrm{C}$ at a rate of $10^{\circ} \mathrm{C} / \mathrm{min}$ for $9 \mathrm{~min}$, and placed in isothermal condition for $2 \mathrm{~min}$. The column oven temperature was maintained at $70^{\circ} \mathrm{C}$. Helium was used as carrier gas with $99.9995 \%$ purity. Samples were injected at a temperature of about $280^{\circ} \mathrm{C}$ with a split ratio of 50 with a flow rate of helium $1.2 \mathrm{ml} / \mathrm{min}$. Mass scan $(\mathrm{m} / \mathrm{z}): 40-700$, MS start time-3.5mins and end time 35 mins. The constituents were identified after comparison with those available in the computer library NIST-11 library (National Institute of Standards and Technology) attached to the instrument and reported.

\section{Molecular Docking}

To identify binding affinities of compounds identified in CSRME and CRRME towards anti- inflammatory protein COX-2 we performed molecular docking studies as per the method described in earlier studies. ${ }^{12}$ The three dimensional protein structures along with the crystallized ligand, AMP (Adenosine monophosphate) were obtained from Protein Data Bank (PDB) PDB ID: 1PXX and 2AW1. Hydrogen atoms were added, water molecules were removed from the cavity to prepare biologically active and stable receptor. The active site within the receptor was identified. Ligands were retrieved from Chemspider and also sketched using tools like Chemdraw. The conformational space of the compounds was employed using an omega (optimized ensemble generation application) program from Open Eye Scientific Software (http://www.eyesopen. com/omega). Ligands were docked onto the receptor and the interactions were checked. The scoring function generates scores depending on which the ligand with the best fit was selected.

\section{Preparation of Chitosan nanoparticles and drug loaded nanoparticles}

Chitosan nanoparticles were prepared by the process of ionic gelation method. ${ }^{13}$ Initially chitosan $(0.4 \%(\mathrm{w} / \mathrm{v}))$ was dissolved in $0.1 \%$ aqueous acetic acid, while the polyanionic solution was prepared by dissolving TPP $(0.2 \% \mathrm{w} / \mathrm{v})$ in deionized water. The polyanionic solution was added drop wise to the chitosan solution under constant stirring and the nanoparticles were obtained spontaneously. For preparation of CS-TPP nanoparticles loaded with various concentrations of CSRME and CRRME (5 mg, $10 \mathrm{mg}$ and $20 \mathrm{mg} / 300 \mu \mathrm{l}$ ) was added to chitosan solution before adding TPP solution. The nanoparticles were centrifuged at $16000 \mathrm{rpm}$ in a glycerol bed for 30 minutes. The supernatant was stored for further analysis and the precipitate was suspended in double distilled water, centrifuged again and dried at $37^{\circ} \mathrm{C}$. The dried chitosan nanoparticles were suspended in Milli-Q-distilled water for further characterization tests, where appropriate or directly used for in vitro release experiments.

\section{Characterization of Chitosan nanoparticles}

Scanning electron microscopy (SEM) of the chitosan nanoparticles was performed to examine the particle size and surface morphology. A suspension of nanoparticles was carefully place on glass cover slip to a glass cover slip followed by air drying. The cover slip itself was using during Scanning Electron Microscopy (SEM) analysis. The samples were then gold coated using a coater attached to the instrument. The image of nano particles were obtained in Carl Zeiss supra 55 GEMIN (German 
Technology) scanning electron microscope under magnification of 5.0 $\mathrm{KX}-75.0 \mathrm{KX}$. The details regarding applied voltage, magnification used and size of the contents of the images were implanted on the image itself. ${ }^{14}$

FTIR

FTIR spectroscopy analyses were carried out using a Jasco Fourier transform infrared spectrometer 410. FTIR spectrophotometer was connected to a photo acoustic cell in the spectral range from 450 to $4000 \mathrm{~cm}^{-1}$.

\section{Biological activity studies}

Evaluation of total antioxidant activity by using DPPH radical scavenging assay

The antioxidant activity of chitosan encapsulated CSRME and CRRME nanoparticles were measured on the basis of the scavenging activity of the stable 1, 1- diphenyl 2-picrylhyorazyl (DPPH) free radical according to the method described with slight modifications. ${ }^{15} 1 \mathrm{ml}$ of $0.1 \mathrm{mM}$ $\mathrm{DPPH}$ solution in methanol was mixed with $1 \mathrm{ml}$ of varying concentrations of C. scariosus and C. rotundus nanoparticles (50, 100, 200, 400, $800,1600$ and $2000 \mu \mathrm{g} / \mathrm{ml})$. Corresponding blank sample were prepared and L-Ascorbic acid $(20,40,60,80$ and $100 \mu \mathrm{g} / \mathrm{ml})$ was used as reference standard. Mixer of $1 \mathrm{ml}$ methanol and $1 \mathrm{ml} \mathrm{DPPH}$ solution was used as control. The reaction was carried out in triplicate and the decrease in absorbance was measured at $517 \mathrm{~nm}$ after $30 \mathrm{~min}$ in dark using UV-Vis spectrophotometer. The inhibition \% was calculated using the following formula.

Where Ac is the absorbance of the control and As is the absorbance of the sample.

\section{In-vitro anti-inflammatory activity using Bovine serum albumin (BSA) denaturation assay}

To evaluate the anti-inflammatory activity present in Chitosan encapsulated C. scariosus and C.rotundus nanoparticles, we used an antidenaturation of BSA assay as per the standard protocols. ${ }^{16}$ In brief, the reaction mixture consist of $0.2 \mathrm{ml}(10 \mathrm{mg} / \mathrm{ml})$ of bovine serum albumin (BSA), $2.8 \mathrm{ml}$ of phosphate buffered saline (PBS, pH-6.4) and $2 \mathrm{ml}$ of varying concentrations of $C$. scariosus and C.rotundus nanoparticles $50,100,200,400,800,1200$ and $1600 \mu \mathrm{g} / \mathrm{ml}$ to a final volume of $5 \mathrm{ml}$. PBS lacking BSA served as control. The samples were incubated at $37 \pm 2^{\circ} \mathrm{c}$ for $15 \mathrm{~min}$ and then transferred to $70^{\circ} \mathrm{C}$ water bath for $5 \mathrm{~min}$. After cooling the sample, the turbidity was measured at $660 \mathrm{~nm}$ using spectrophotometer. The anti-inflammatory activity of phytochemical compounds was determined by plotting the percentage of inhibition with respect to control against treatment condition. In the present study diclofenac sodium was used as a positive anti-inflammatory drug. The percentage inhibition of protein denaturation was calculated by using the following formula.

$$
\text { Percentage of Inhibition }=\frac{A c-A s}{A c}, 100
$$

Where $\mathrm{Vt}=$ Absorbance of test Sample, $\mathrm{V}_{\mathrm{c}}=$ Absorbance of Control.

\section{Determination of total Phenolic content}

The concentration of phenolics in chitosan prepared nanoparticles were determined using spectrophotometric method. ${ }^{17}$ The reaction mixture was prepared by mixing $0.5 \mathrm{ml}$ of varying concentrations of C. scariosus and $C$. rotundus nanoparticles $(50,100,200,400,800,1600$ and $2000 \mu \mathrm{g} / \mathrm{ml})$, $2.5 \mathrm{ml}$ of $10 \%$ Folin-Ciocalteu's reagent dissolved in water and $2.5 \mathrm{ml}$ of $7.5 \% \mathrm{NaHCO}_{3}$. Blank was concomitantly prepared, containing $0.5 \mathrm{ml}$ DMSO, $2.5 \mathrm{ml}$ 10\% Folin-Ciocalteu's reagent dissolved in water and $2.5 \mathrm{ml}$ of $7.5 \%$ of $\mathrm{NaHCO}_{3}$. The samples were there after incubated in a thermostat at $45^{\circ} \mathrm{C}$ for $45 \mathrm{~min}$. The absorbance was determined using spectrophotometer at $\lambda_{\max }=765 \mathrm{~nm}$. The samples were prepared in triplicate for each analysis and the mean value of absorbance was obtained. The same procedure was repeated for the standard solution of gallic acid and the calibration line was construed. Based on the measured absorbance, the concentration of phenolics was read $(\mathrm{mg} / \mathrm{ml})$ from the calibration line, then the content of phenolics in extracts was expressed in terms of gallic acid equivalents (mg of GA/g of extract).

\section{Statistical analysis}

All the experiments were carried out in triplicates and the data reported are mean \pm standard deviation. Calculation of linear correlation coefficient and correlation analysis were carried out using MS office Excel 2007. The linear regression equation for straight line is $\mathrm{Y}=\mathrm{mx}+\mathrm{c}$. $\mathrm{Y}=$ Absorbance of extract, $\mathrm{m}=$ Slope of the calibration curve, $\mathrm{X}=$ Concentration of extract, $\mathrm{C}=$ intercept. Using this regression equation concentration of extracts was calculated. From the calculated values of concentration of each extract, the total phenolic content was calculated.

\section{RESULTS}

\section{Comparative phytochemical and elemental analysis between C. scariosus and C. Rotundus}

For the comparative phytochemical analysis, rhizomes were collected, crushed and milled to a fine powder. The powder showed a distinct colour variation between the species. However, classifying the species based on colour can be erratic and misleading. In order to identify the compounds present in the methanolic extract, the CSRME (Cyperus scariosus rhizome methanolic extract) and CRRME (Cyperus rotundus rhizome methanolic extract) were subjected to thin layer chromatographic (TLC) analysis. Single bands (under visible light) were observed from thin layer chromatograms between methanol extracts of CSRME with an $R_{f}$ value of 0.857 and CRRME with an $R_{f}$ value of 0.625 as shown in (Figure 1). Based on the $R_{f}$ value, it is speculated that the higher $\mathrm{R}_{\mathrm{f}}$ value is due to the presence of a greater number of phytochemical constituents. Further we evaluated elemental composition in methanolic extracts of both plant species using SEM-EDAX analysis. Scanning electron microscopy of the CSRME and CRRME rhizome powders was performed to examine the surface morphology. The images of rhizome powders of both the herbs were obtained in Carl Zeiss Supra 55 Gemin scanning electron microscope. In CSRME under magnification at 296 $\mathrm{X}$ showed large granule like structure. Later, we also performed EDAX analysis of these granules of CS. The SEM - EDAX spectra of the CS granule showed the carbon, oxygen, sodium, chloride and silica peaks possibly omitted at $2.137 \mathrm{KeV}$ with number of four iterations (Figure 2). Where as in case of CRRME under magnification at $250 \mathrm{X}$ showed small granules like structures. Elements carbon, oxygen, sodium, potassium and chloride peaks possibly omitted at 2.144 and $9.717 \mathrm{KeV}$ with four number of iterations (Figure 3). Here $\mathrm{CaCO}_{3}, \mathrm{SiO}_{2}, \mathrm{MgO}, \mathrm{KCl}, \mathrm{MAD}$, Wallastonites are used as standards. By comparing the results of EDAX showed the presence of trace elements such as $\mathrm{C}, \mathrm{O}, \mathrm{Na}, \mathrm{Cl}$ and $\mathrm{Si}$ in C. scariosus. Whereas in case of C. rotundus $\mathrm{C}, \mathrm{O}, \mathrm{Na}, \mathrm{Cl}$ and $\mathrm{K}$. Defiency of these trace elements in human subjects can occur under the most practical dietary conditions and in much diseased status. In recent years, scientist and nationalists have started believing in the therapeutic role of metals in human health. Trace elements play both curative and preventive role in combating diseases. Over all microscopic analysis of CS and CR indicated the presence of carbon, oxygen, sodium, and chlorine in both samples. However, the percentage of carbon and oxygen were predominant in both the powder samples and they showed a significant variation across the species. Trace amounts of sodium, chlorine and potassium were observed in both C. scariosus and C. Rotundus, although silica was restricted to C. scariosus only. These trace elements are estimated by determining the percentage abundance (\%) of elements carbon, oxygen, sodium, chlorine, potassium and silica in these samples. 
Table 1: The percentage of trace elements in CSRME and CRRME

\begin{tabular}{ccccccc}
\hline & \multicolumn{3}{c}{ C. scariosus (CS) } & \multicolumn{3}{c}{ C. rotundus (CR) } \\
\hline S.No & Element & Weight\% & Atomic\% & Element & Weight\% & Atomic\% \\
\hline 1 & C K & 58.06 & 65.31 & CK & 46.04 & 55.44 \\
2 & O K & 39.87 & 33.67 & OK & 43.61 & 39.43 \\
3 & Na K & 1.02 & 0.60 & NaK & 4.29 & 2.70 \\
4 & Si K & 0.24 & 0.11 & ClK & 5.21 & 2.13 \\
5 & Cl K & 0.80 & 0.31 & KK & 0.84 & 0.31 \\
6 & Total & 100.00 & 100.00 & Total & 100 & 100.00 \\
\hline
\end{tabular}

Trace elements are estimated by determining the percentage abundance (\%) of elements in CS and CR.

Table 2: Compounds identified in the partially purified extract of Cyperus scariosus in GC-MS

\begin{tabular}{|c|c|c|c|c|c|}
\hline S.No & $\begin{array}{c}\text { Peak area } \\
\%\end{array}$ & $\begin{array}{l}\text { Retention } \\
\text { time }\end{array}$ & Compound name & Formula & $\begin{array}{c}\text { Molecular } \\
\text { weight }\end{array}$ \\
\hline \multirow[t]{4}{*}{1} & 9.84 & 3.765 & a. 2-propane,1-hydroxy-oxime & $\mathrm{C}_{3} \mathrm{H}_{7} \mathrm{NO}_{2}$ & 89.09 \\
\hline & & & b. 2,4,6,8 Tetra azabicyclo & $\mathrm{C}_{4} \mathrm{H}_{6} \mathrm{~N}_{6} \mathrm{O}_{3}$ & 186.129 \\
\hline & & & [3.3.0] octan-3-one-7-nitroimino & & \\
\hline & & & c. Propanedioic acid, Propyl dimethyl ester & $\mathrm{C}_{8} \mathrm{H}_{14} \mathrm{O}_{4}$ & 174.19 \\
\hline 2 & 4.57 & 14.344 & Diethylpthalate & $\mathrm{C}_{12} \mathrm{H}_{14} \mathrm{O}_{4}$ & 222.23 \\
\hline 3 & 73.82 & 15.064 & Benzenepropanamide,N,N- dimethyl & $\mathrm{C}_{11} \mathrm{H}_{15} \mathrm{NO}$ & 177.242 \\
\hline \multirow[t]{2}{*}{4} & 15.064 & 73.82 & a. Galactitol & $\mathrm{C}_{6} \mathrm{H}_{14} \mathrm{O}_{6}$ & 182.17 \\
\hline & & & b. Trimethylsilyl methanol & $\mathrm{C}_{4} \mathrm{H}_{12} \mathrm{OSi}$ & 104.223 \\
\hline \multirow[t]{3}{*}{5} & 2.39 & 16.632 & a. Octadecene & $\mathrm{C}_{18} \mathrm{H}_{36}$ & 252.47 \\
\hline & & & b.E-15-Heptadecenal & $\mathrm{C}_{17} \mathrm{H}_{32} \mathrm{O}$ & 252.43 \\
\hline & & & c. 9-Eicosene,(E)- & $\mathrm{C}_{20} \mathrm{H}_{40}$ & 280.31 \\
\hline \multirow[t]{4}{*}{6} & 2.71 & 18.682 & a. Acetic acid, chloro-octadecyl ester & $\mathrm{C}_{20} \mathrm{H}_{39} \mathrm{ClO}_{2}$ & 346.97 \\
\hline & & & b. Hepta fluorobutyric acid, penta decyl ester & $\mathrm{C}_{18} \mathrm{H}_{29} \mathrm{~F}_{7} \mathrm{O}_{2}$ & 410.41 \\
\hline & & & c. 1-Docosene & $\mathrm{C}_{22} \mathrm{H}_{44}$ & 308.58 \\
\hline & & & a. Tri chloro acetic acid, hexadecyl ester & $\mathrm{C}_{18} \mathrm{H}_{33} \mathrm{Cl}_{3} \mathrm{O}_{2}$ & 387.812 \\
\hline \multirow[t]{3}{*}{7} & 2.77 & 20.554 & b. Hepta fluoro butyric acid pentadecyl ester & $\mathrm{C}_{19} \mathrm{H}_{31} \mathrm{~F}_{7} \mathrm{O}_{2}$ & 424.431 \\
\hline & & & c. Behenic alcohol & $\mathrm{C}_{22} \mathrm{H}_{46} \mathrm{O}$ & 326.60 \\
\hline & & & a. 1-Docosanethiol & $\mathrm{C}_{22} \mathrm{H}_{46} \mathrm{~S}$ & 342.66 \\
\hline \multirow[t]{3}{*}{8} & 1.76 & 22.27 & b. $1 \mathrm{H}$-indole,5-methyl-2-phenyl & $\mathrm{C}_{15} \mathrm{H}_{13} \mathrm{~N}$ & 207.27 \\
\hline & & & c. 17-pentatriacontene & $\mathrm{C}_{35} \mathrm{H}_{70}$ & 490.93 \\
\hline & & & a. 2-ethyl acridine & $\mathrm{C}_{15} \mathrm{H}_{13} \mathrm{~N}$ & 207.27 \\
\hline 9 & 2.14 & 23.369 & b. 2,3,5,6-Tetra fluoro phenyl iso thio cyanate & $\mathrm{C}_{7} \mathrm{HF}_{4} \mathrm{NS}$ & 207.14 \\
\hline
\end{tabular}

The concentration of such elements and these samples were represented in (Table 1).

\section{Gas Chromatography-mass spectroscopy analysis of C. scariosus and C. rotundus rhizomes methanolic extract.}

The compounds present in the CSRME and CRRME were identified by GC-MS analysis (Figure $4 \mathrm{a} \& \mathrm{~b}$ ). The active principles with their retention time, molecular formula and molecular weight in these extracts were presented in (Table $2 \&$ Table 3 ).

\section{Comparative molecular docking analysis between CSRME and CRRME compounds}

To identify the potential bioactive compounds against COX-2 (PDB ID: 1 PXX and 2AW1), GC-MS derivatives of C. scariosus and C. rotundus consist of 9 peaks (21 metabolites) and 10 peaks (22 metabolites) respectively. A total of 43 compounds were merged along with the wellknown anti-inflammatory compound diclofenac as a single database using VIDA. To generate the best binding conformation pose, all the compounds were employed using the Omega (an optimised ensemble generation application) program from Open Eye Scientific Software (http://www.eyesopen.com/omega) to generate a maximum of 200 conformers per molecule. Thirteen molecules were unable to generate conformation poses and the remaining 40 compounds were subjected to molecular docking using the FRED engine. The results showed thirteen compounds (six from C. scariosus and seven from C. Rotundus) were fit into the cavity of COX-2 protein (Table 4). Among all the compounds, the $\mathrm{N}$-isopropyl ethylene diamine of the $C$. rotundus compound formed three hydrogen bond contacts at the $16^{\text {th }} 19^{\text {th }}$ and $20^{\text {th }}$ positions of Ser 530 and Tyr 385 aminoacids of 1PXX, with the lowest energy of -5.13 $\mathrm{K} . \mathrm{cal} / \mathrm{mol}$, (Figure $5 \mathrm{~b}$ ) and $19^{\text {th }}$ position of Thr 200 aminoacid of $2 \mathrm{AW} 1$, with the lowest energy of $4.56 \mathrm{~K} . \mathrm{cal} / \mathrm{mol}$ (Figure $5 \mathrm{e}$ ). However, the binding energy between COX-2 and diclofenac is $-10.93 \mathrm{kcal} / \mathrm{mol}$, which is nearer to the binding energy of COX-2 and the 2, 3, 5, 6-Tetra fluoro phenyl isothiocyanate complex $(-10.25 \mathrm{Kcal} / \mathrm{mol}) .2$, 3, 5, 6-Tetra fluoro phenyl isothiocyanate forms a single hydrogen bond interaction with Ser 
Table 3: Compounds identified in the partially purified extract of Cyperus rotundus in GC-MS

\begin{tabular}{|c|c|c|c|c|c|}
\hline S.No & Peak area\% & $\begin{array}{l}\text { Retention } \\
\text { time }\end{array}$ & Compound name & Formula & $\begin{array}{c}\text { Molecular } \\
\text { weight }\end{array}$ \\
\hline \multirow[t]{2}{*}{1} & 21.38 & 11.677 & a. Phenol,2-propyl & $\mathrm{C}_{19} \mathrm{H}_{12} \mathrm{O}$ & 136.19 \\
\hline & & & b. Phenol,4-propyl & $\mathrm{C}_{19} \mathrm{H}_{12} \mathrm{O}$ & 136.19 \\
\hline 2 & 3.05 & 11.833 & 2-furyl alpha-hydroxy benzyl ketone & $\mathrm{C}_{12} \mathrm{H}_{10} \mathrm{O}_{3}$ & 202.2 \\
\hline \multirow[t]{4}{*}{3} & 34.86 & 12.501 & a.1-beta-d-ribofuranosyl-3-[5-tetraazolyl]- & $\mathrm{C}_{8} \mathrm{H}_{11} \mathrm{~N}_{7} \mathrm{O}_{4}$ & 269.218 \\
\hline & & & $1,2,4-$ triazole & & \\
\hline & & & b. N-isopropylethylene diamine & $\mathrm{C}_{6} \mathrm{H}_{14} \mathrm{~N}_{2}$ & 102.18 \\
\hline & & & c. 1,3,2,5-Dimethylene-1-rhamnitol & $\mathrm{C}_{8} \mathrm{H}_{14} \mathrm{O}_{5}$ & 190.19 \\
\hline \multirow[t]{3}{*}{4} & 8.01 & 14.373 & a. Dichloro acetic acid,tridecyl ester & $\mathrm{C}_{15} \mathrm{H}_{28} \mathrm{Cl}_{2} \mathrm{O}_{2}$ & 311.28 \\
\hline & & & b. 4-Trifluoro acetoxy tetradecane & $\mathrm{C}_{16} \mathrm{H}_{29} \mathrm{~F}_{3} \mathrm{O}_{2}$ & 310.39 \\
\hline & & & c. 1-Hexadecanol & $\mathrm{C}_{16} \mathrm{H}_{34} \mathrm{O}$ & 242.44 \\
\hline \multirow[t]{3}{*}{5} & 13.96 & 15.034 & a. $1,2,3,4$-Butanetetrol $\left(\mathrm{S}-\mathrm{R}^{\star}, \mathrm{R}^{\star}\right)$ & $\mathrm{C}_{4} \mathrm{H}_{10} \mathrm{O}_{4}$ & 122.11 \\
\hline & & & b. Diisopropylamine & $\mathrm{C}_{6} \mathrm{H}_{15} \mathrm{~N}$ & 101.19 \\
\hline & & & $\begin{array}{l}\text { c. Malonic acid, 1,3-dithio-bimol cyclic S,S- } \\
\text { ethylene ester }\end{array}$ & $\mathrm{C}_{10} \mathrm{H}_{12} \mathrm{O}_{4} \mathrm{~S}_{4}$ & 324.45 \\
\hline \multirow[t]{3}{*}{6} & 2.72 & 15.458 & $\begin{array}{c}\text { a.2-Amino -5H-pyrrolo [3,4-d]pyrimidine- } \\
4,7(3 \mathrm{H}, 7 \mathrm{H}) \text {-dione }\end{array}$ & $\mathrm{C}_{6} \mathrm{H}_{6} \mathrm{~N}_{4} \mathrm{O}_{2}$ & 166.138 \\
\hline & & & b. 3-chloro-N-methylpropylamine & $\mathrm{C}_{4} \mathrm{H}_{10} \mathrm{ClN}$ & 107.58 \\
\hline & & & c. 2,4-dimethoxyamphetamine & $\mathrm{C}_{11} \mathrm{H}_{17} \mathrm{NO}_{2}$ & 195.25 \\
\hline \multirow[t]{4}{*}{7} & 6.14 & 16.26 & $\begin{array}{l}\text { a.7-isopropenyl-1,4a-dimethyl-4,4a,5,6,7,8- } \\
\text { hexahydro-3H-naphthalene-2-one }\end{array}$ & $\mathrm{C}_{15} \mathrm{H}_{22} \mathrm{O}$ & 218.33 \\
\hline & & & b.2(1H)Naphthalenone, $3,5,6,8,8,8 \mathrm{a}-\mathrm{hexa}$ & $\mathrm{C}_{15} \mathrm{H}_{22} \mathrm{O}$ & 218.33 \\
\hline & & & hydro-4,8a-dimethyl-6(1-methylethenyl)- & & \\
\hline & & & c. Aromadendrene & $\mathrm{C}_{15} \mathrm{H}_{24}$ & 204.35 \\
\hline \multirow[t]{3}{*}{8} & 4.13 & 16.639 & a. Tetradecyl trifluoro acetate & $\mathrm{C}_{16} \mathrm{H}_{29} \mathrm{~F}_{3} \mathrm{O}_{2}$ & 310.39 \\
\hline & & & b. Trifluoroacetic acid,n-tridecyl ester & $\mathrm{C}_{15} \mathrm{H}_{27} \mathrm{~F}_{3} \mathrm{O}_{2}$ & 296.36 \\
\hline & & & c. Pentafluoro propionic acid tetrad & $\mathrm{C}_{2} \mathrm{~F}_{5} \mathrm{COOH}$ & 164.03 \\
\hline \multirow[t]{3}{*}{9} & 3.49 & 18.682 & a. Trichloro acetic acid,pentadecyl ester & $\mathrm{C}_{17} \mathrm{H}_{31} \mathrm{Cl}_{3} \mathrm{O}_{2}$ & 373.78 \\
\hline & & & b. Dichloro acetic acid,heptadecyl ester & $\mathrm{C}_{19} \mathrm{H}_{36} \mathrm{Cl}_{2} \mathrm{O}_{2}$ & 367.393 \\
\hline & & & c. 1-docosene & $\mathrm{C}_{22} \mathrm{H}_{44}$ & 308.58 \\
\hline \multirow[t]{3}{*}{10} & 2.27 & 20.546 & a. Bromoacetic acid,hexadecyl ester & $\mathrm{C}_{18} \mathrm{H}_{35} \mathrm{BrO}_{2}$ & 363.373 \\
\hline & & & b. Bromoacetic acid,pentadecyl ester & $\mathrm{C}_{17} \mathrm{H}_{33} \mathrm{BrO}_{2}$ & 349.34 \\
\hline & & & c. Penta fluoro propionic acid,tridecyl ester & $\mathrm{C}_{16} \mathrm{H}_{27} \mathrm{~F}_{5} \mathrm{O}_{2}$ & 346.376 \\
\hline
\end{tabular}

530 of 1 PXX in Figure 5c and Thr 200 of 2AW1 in Figure 5f. This similar free energy value and hydrogen bond interaction suggests similar functions as relevant to crystallised ligands with COX2 (Figure 5a and d). Moreover, 2, 3, 5, 6-Tetra fluoro phenyl isothiocyanate showed a 90\% overlap with N, N-Dichloro-4-methylbenzenesulfonamide ( Figure 6), a well-known compound used to treat infected wounds. ${ }^{18}$

\section{The role of extract loaded chitosan nanoparticles on chemopreventive properties}

To minimise the toxic effects of organic solvent and to maximise the efficacy of pharmacological properties like antioxidant and anti-inflammatory activities, we encapsulated methanol extracts of C. scariosus and C. rotundus into chitosan nanoparticles. The prepared nanoparticles were characterised using scanning electron microscopy (SEM), which is a complementary technique in pharmacognostic evaluation. SEM images showed that blank nanoparticles are spherical in shape and are well-dispersed; their size is consistent with the SEM observation (100 $500 \mathrm{~nm}$ ) Figure 7(a). C. scariosus nanoparticles are separated from each other and appear to be homogeneous, smooth and spherical in shape, which is confirmed by surface morphology studies. These particles did not form aggregation after lyophilisation and were readily re dispersible Figure 7(b). C. rotundus nanoparticles showed a moderate uniformity and formed an aggregate, which may be due to the strong inter particle interaction during preparation Figure 7 (c). To identify the molecular distribution of the phytochemicals in the molecular scaffold of the polymeric chitosan nanoparticles, we recorded the infrared spectra using a Fourier transform spectrometer. The FTIR spectra showed several characteristic absorption peaks and variable stretching for different extracts. The CSRME extract showed six major peaks at $3061 \mathrm{~cm}^{-1}(=\mathrm{C}$ $\mathrm{H}), 2886 \mathrm{~cm}^{-1}(=\mathrm{C}-\mathrm{H}), 2630 \mathrm{~cm}^{-1}(\mathrm{COOH}), 2043 \mathrm{~cm}^{-1}, 1730 \mathrm{~cm}^{-1}(\mathrm{C}=\mathrm{O})$ and $944 \mathrm{~cm}^{-1}\left(=\mathrm{C}-\mathrm{H}\right.$ and $=\mathrm{CH}_{2}$ ) (Figure $7 \mathrm{~d}$ ). Unlike CSRME, CRRME showed different wavelength peaks at $3497 \mathrm{~cm}^{-1}(\mathrm{OH}), 3061 \mathrm{~cm}^{-1}(\mathrm{C}-\mathrm{H})$, $1624 \mathrm{~cm}^{-1}(\mathrm{C}=\mathrm{C}), 1258 \mathrm{~cm}^{-1}(\mathrm{C}-\mathrm{F})$, and $960 \mathrm{~cm}^{-1}\left(=\mathrm{C}-\mathrm{H}\right.$ and $\left.=\mathrm{CH}_{2}\right)$ respectively. The carboxylic acid $\mathrm{C}=0$ stretch and $\mathrm{C}=\mathrm{C}-\mathrm{H}$ aromatic asymmetric stretch of the CSRME extract at 1685 and 3008.7 are shifted towards 1730 and 3061 of CSRME loaded chitosan nanoparticles respectively. Similarly, the $\mathrm{C}-\mathrm{C}=\mathrm{C}$ aromatic symmetric stretch and alcohol/phenol O-H stretch at 1640.8 and 3464.7 are shifted towards 1624.5 and 3497.2, respectively (Figure 7e). The shifted peaks are easily distinguishable from blank nanoparticles. The encapsulation efficiency (EE) of CSRME and CRRME into chitosan nanoparticles was determined via the FolinCiocalteu method using gallic acid as the standard. As shown in Figure 8 , the concentration of phenolic content increased in a dose dependent manner. 
Table 4 Comparative molecular docking compounds in C. scariosus and C. Rotundus

\begin{tabular}{|c|c|c|c|c|c|}
\hline S.No & Compound & $1 \mathrm{PXX}$ & 2AW1 & $\begin{array}{c}\text { Bond } \\
\text { Distance }\end{array}$ & $\begin{array}{c}\text { Hybrid Chemgauss } 4 \\
\text { score }\end{array}$ \\
\hline 1 & 1H-indole,5-methyl-2-phenyl & & & 2.31 & -12.5 \\
\hline 2 & Phenol,4-propyl & & & 2.34 & -9.375 \\
\hline \multirow[t]{2}{*}{3} & Propanedioic acid,propyl, dimethyl ester & & & 2.36 & -8.591 \\
\hline & Hepta fluoro butyric acid pentadecyl ester & & & & \\
\hline \multirow[t]{2}{*}{4} & Ethyl acridine & Ser 530 & & 2.42 & -6.064 \\
\hline & Phenol,2-propyl & & & & \\
\hline 5 & 3-chloro-N-methylpropylamine & & & 4.81 & -15.189 \\
\hline 6 & $2,3,5,6$-Tetra fluoro phenyl isothiocyanate & & & 2.39 & -9.982 \\
\hline 7 & Pentafluoro propionic acid tetrade & & & 2.18 & -6.0723 \\
\hline 8 & & & Thr 199 & 2.10 & -10.257 \\
\hline 9 & & & Asn 67 & 1.94 & -8.05 \\
\hline \multirow[t]{3}{*}{11} & $\mathrm{~N}$-isopropyl ethylene diamine & Ser 530 & & & \\
\hline & & Ser 530 & Thr 200 & & -5.13892 \\
\hline & & Tyr 385 & & & \\
\hline 12 & Trimethylsilyl methanol & Tyr 385 & & & -6.582 \\
\hline \multirow[t]{3}{*}{13} & 2-Amino-5H-pyrrolo[3,4-d]pyrimidine-4,7(3H,7H)-dione & & Asn 67 & 2.36 & \\
\hline & & & $\mathrm{Gln} 92$ & 2.47 & -7.24 \\
\hline & & & Thr 200 & 1.99 & \\
\hline 14 & Malonic acid,1,3-dithio-bimol.cyclic S,S-ethylene ester & & Gln & 2.35 & -6.69 \\
\hline \multirow[t]{4}{*}{15} & Diclofenac & Ser 530 & & 1.9 & -10.93 \\
\hline & & Val 523 & & 1.9 & \\
\hline & & & Thr 199 & 2.06 & -8.90 \\
\hline & & & Thr 200 & 1.77 & \\
\hline
\end{tabular}
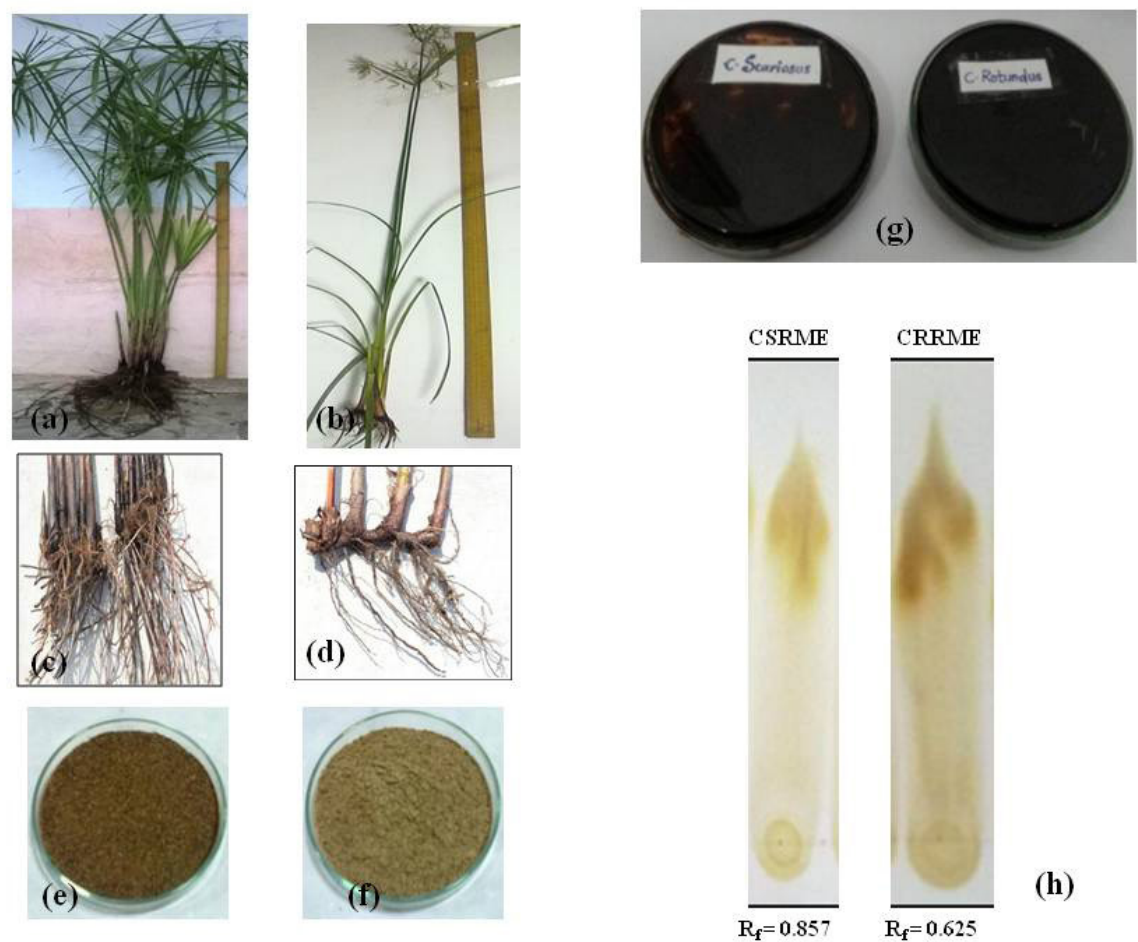

(h)

Figure 1: Comparision of phenotypic attributes (a \& b) whole plants of C. scariosus $\mathrm{R}$. Br (CS) and C. rotundus L (CR). (c \& d) rhizomes. (e \& f) rhizomes powders of CS and CR. (g) Benzene insoluble extract and (h). TLC chromatogram of CS and CR methanolic extract. 


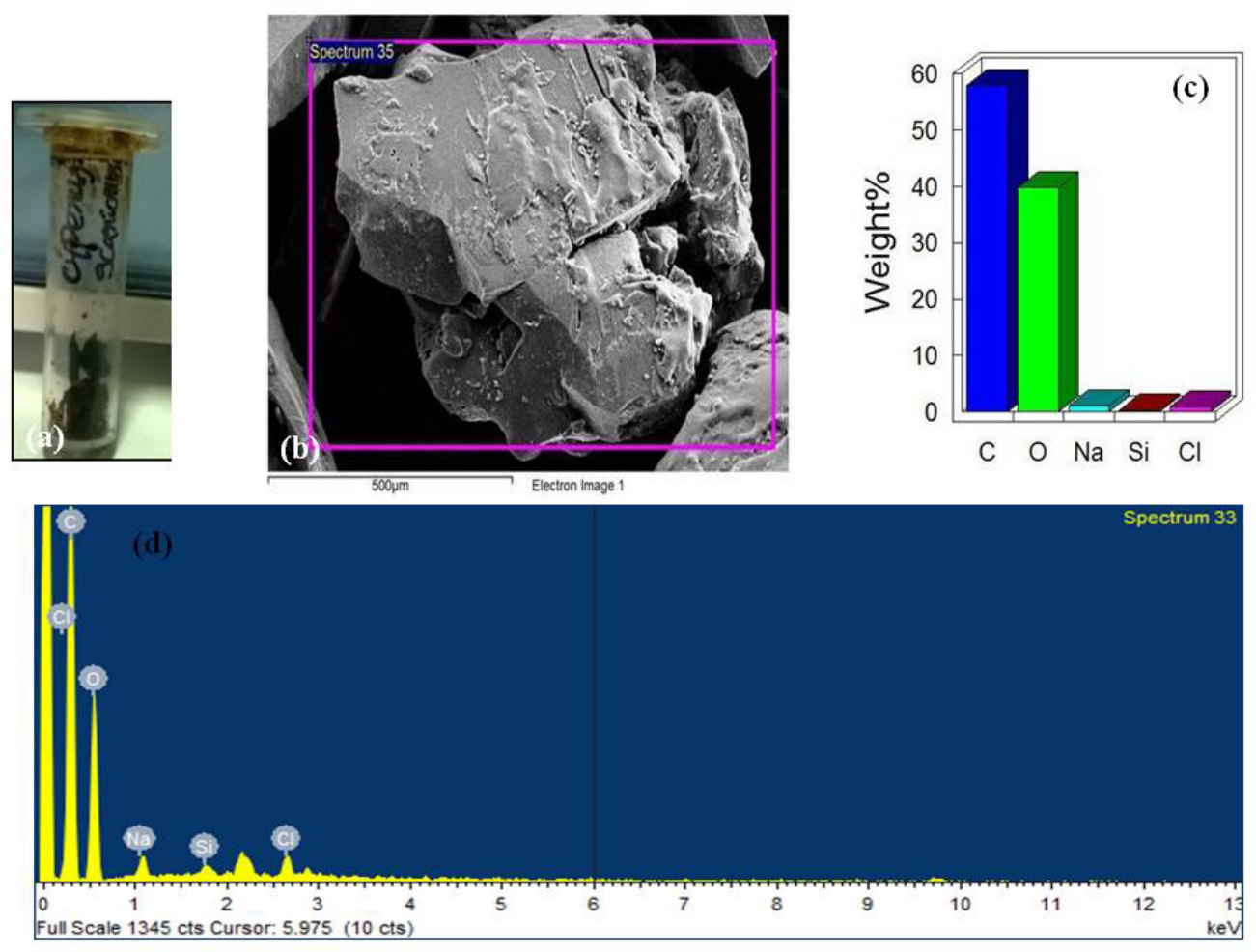

Figure 2: Represents elemental analysis in C. scariosus R. Br. (a). Partially purified methanolic extract (CSRME). (b). SEM image of CSRME. (c) Quantitative results of elements. (d). EDAX spectrum of CSRME.
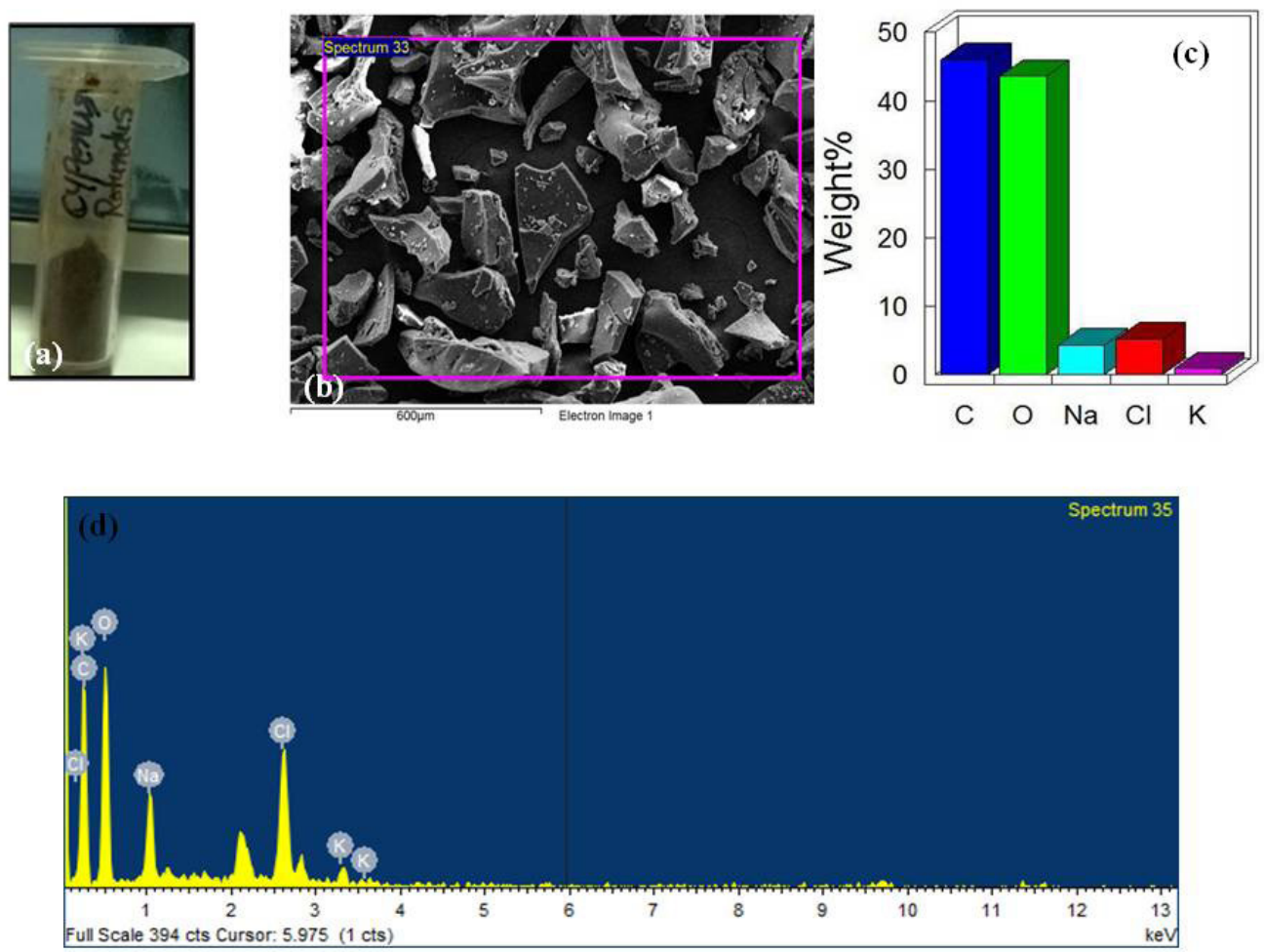

Figure 3: Represents elemental analysis in C. rotundus L. (a). Partially purified methanolic extract (CRRME). (b). SEM image of CRRME. (c) Quantitative results of elements. (d). EDAX spectrum of CRRME. 
(a)

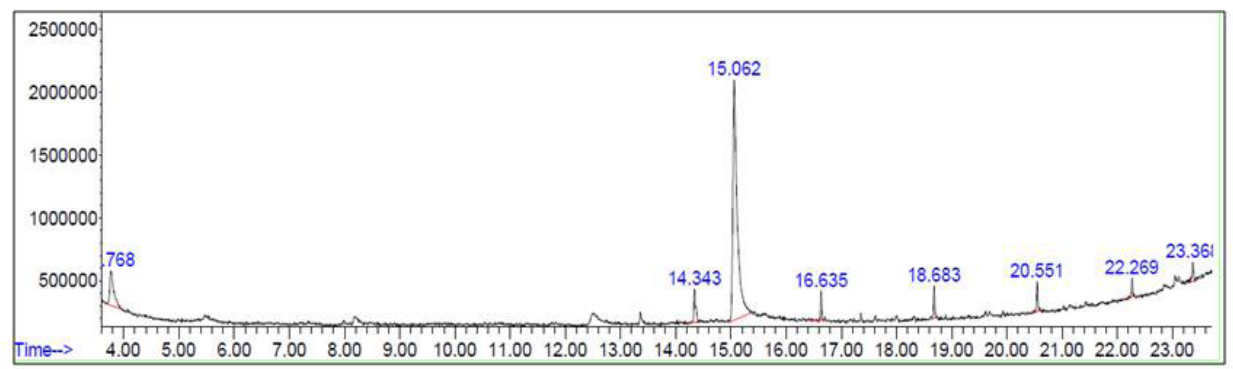

(b)

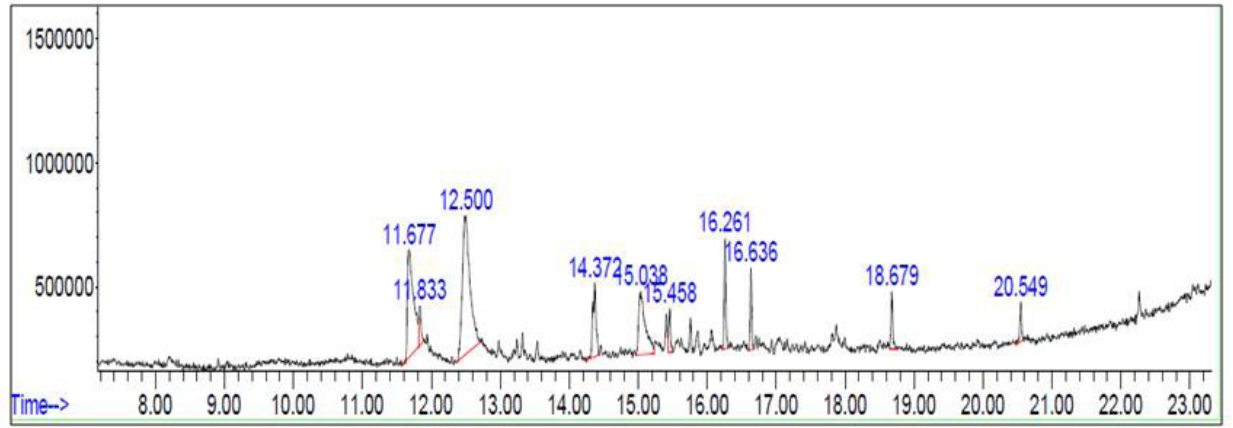

Figure 4: Representative GC-MS chromatograms of methanolic extracts of (a) C. scariosus and (b) C. rotundus.

(a)

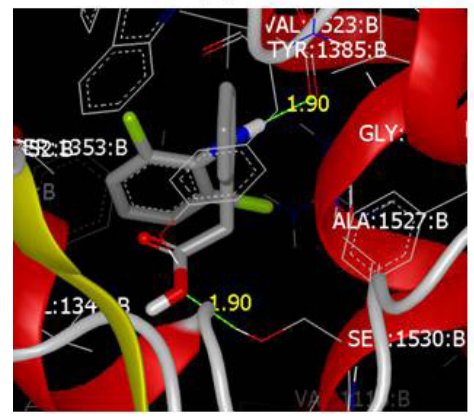

(d)

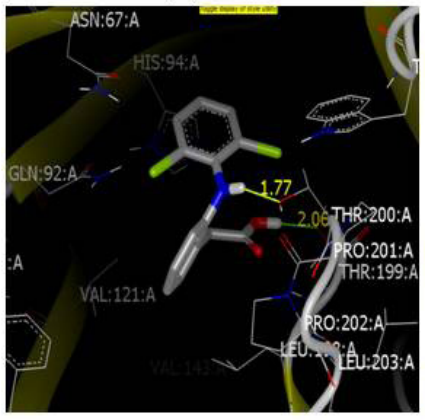

(b)

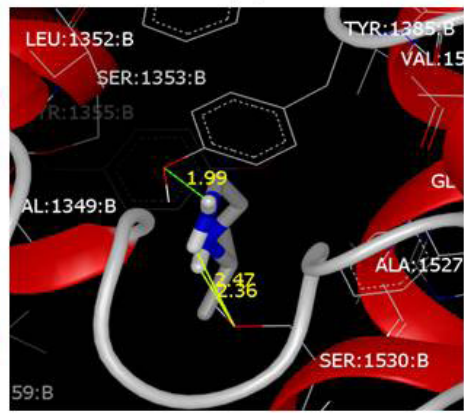

(e)

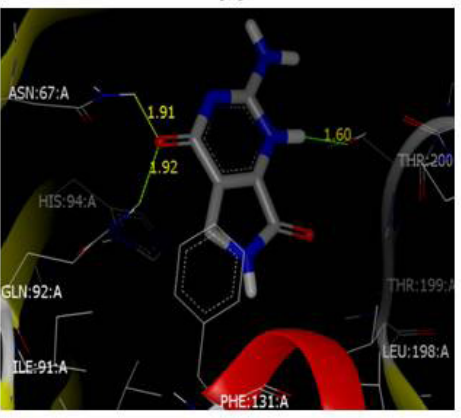

(c)

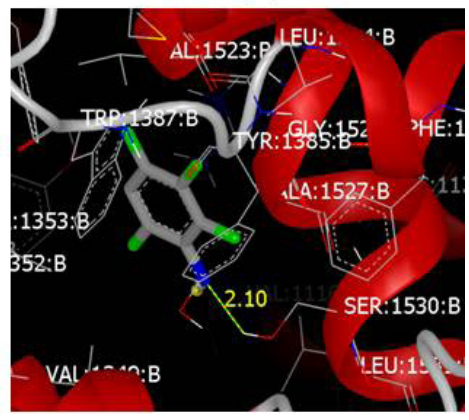

(f)

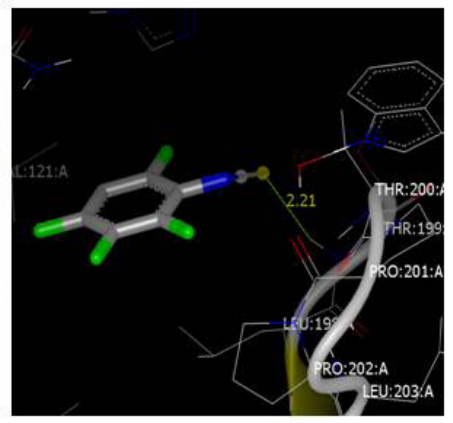

Figure 5: In silico molecular docking. Top panel: Protein-drug interaction against COX protein (PDB ID: 1PPX) with Diclofenac standard and plant compounds. Bottom panel: Protein-plant compound interaction against COX protein (PDB ID: 2AW1) plant compounds. Green dotted lines depict the H-bond interactions with aminoacid residues; yellow colored numbers indicates the H-bond distance in Angstroms $(\AA)$. 
(a)

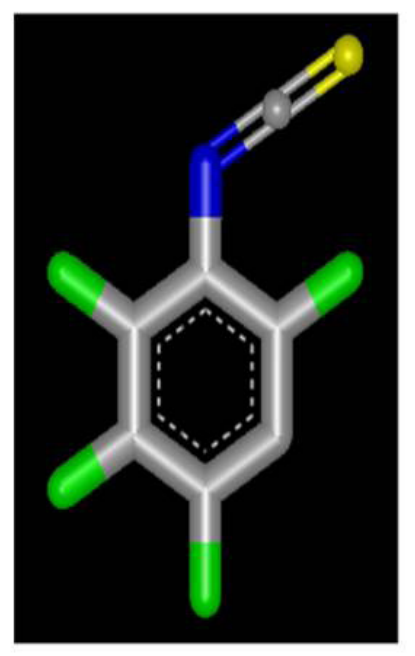

(b)

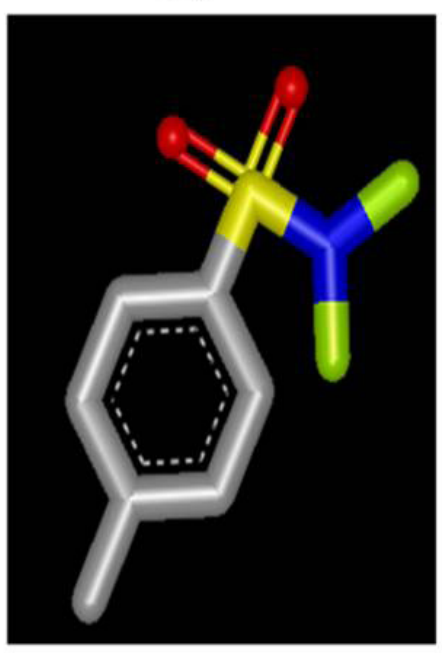

(c)

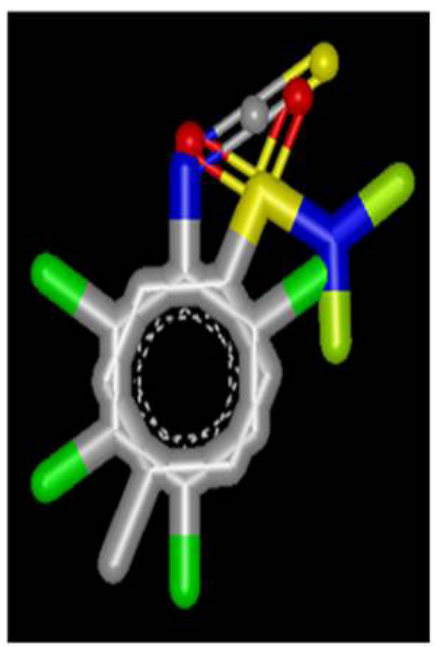

Figure 6: Compound in CSRME (a) 2,3,5,6- Tetra fluro phenyl isothiocyanate showed similar functions as relevant to crystallized ligand with Cox-2 (b) N,N-Dichloro-4-methyl benzene sulfonamide. (c) Represents overlay structures of 2,3,5,6-Tetra fluro phenyl isothiocyanate and N,N-Dichloro4-methyl benzene sulfonamide.

(a)

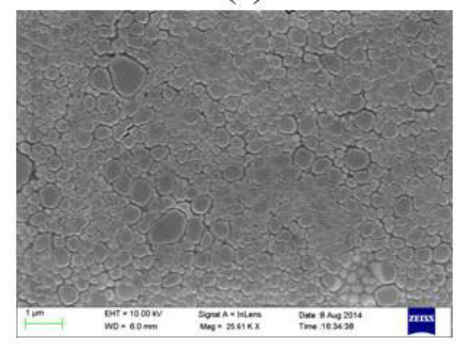

(d)

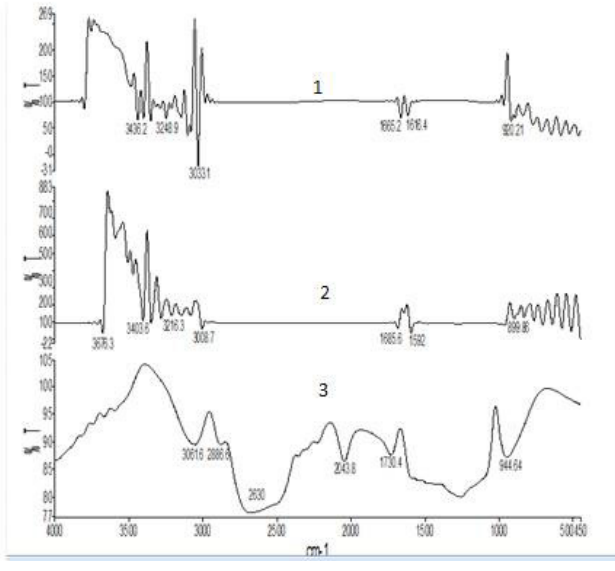

(b)

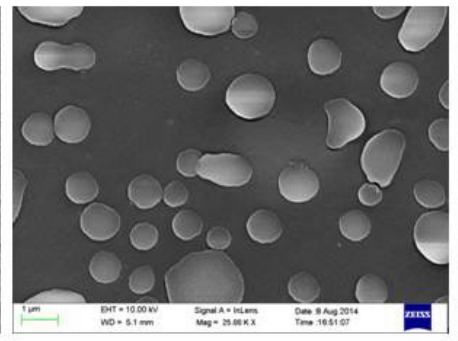

(c)

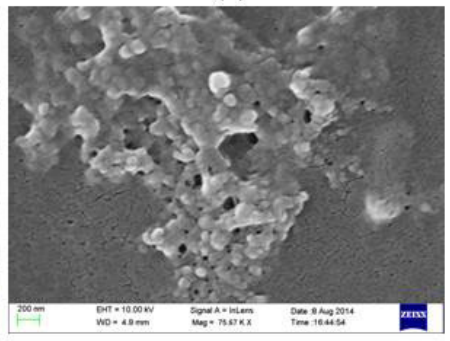

(e)

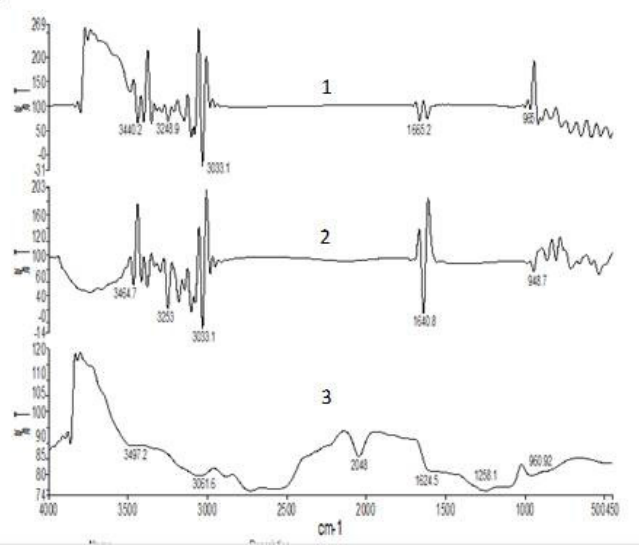

Figure 7: Comparative SEM microphotographs (a) Chitosan blank nanoparticles (b) Chitosan encapsulated CSRME nanoparticles (c) Chitosan encapsulated CRRME nanoparticles. Comparison between FT-IR spectrums (d) CSRME and (e) CRRME (1) Chitosan blank nanoparticles (2) Chitosan encapsulated active band of plant extract (3) Methanolic extract of active band of plant extract. 
(a)

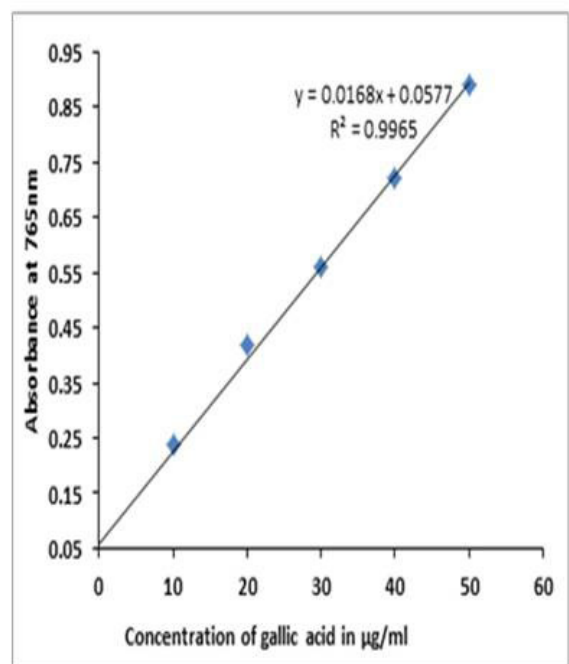

(b)

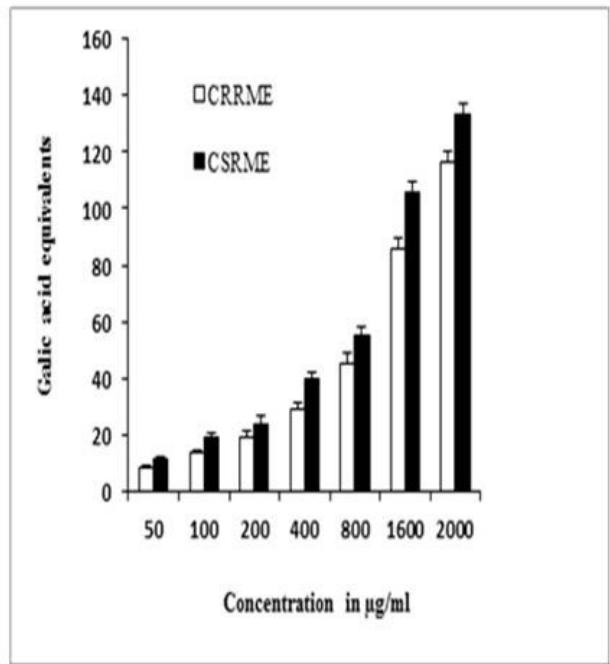

Figure 8: Encapsulation efficiency by using Phenolic assay (A) Calibration curve of Gallic acid [ $\mu \mathrm{g} / \mathrm{mL}$ ] (B) Comparison of CSRME and CRRME nanoparticles $[\mu \mathrm{g} / \mathrm{mL}]$. Graphs are presented as mean \pm SEM of three independent experiments.

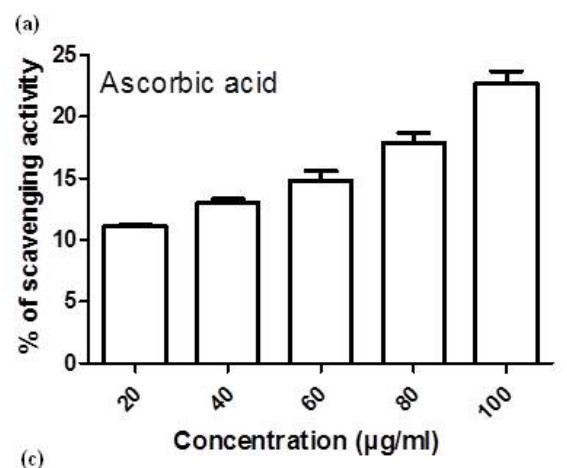

(c)

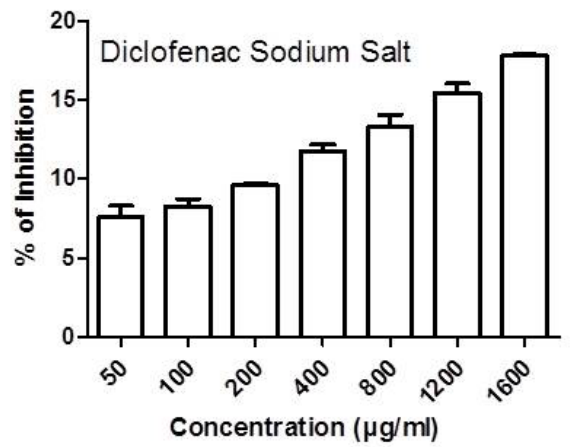

(b)

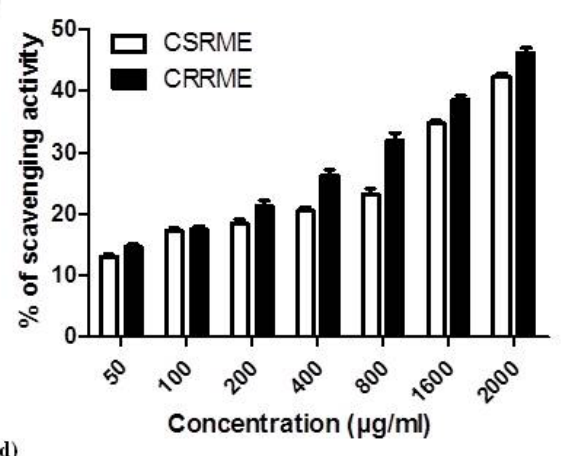

(d)

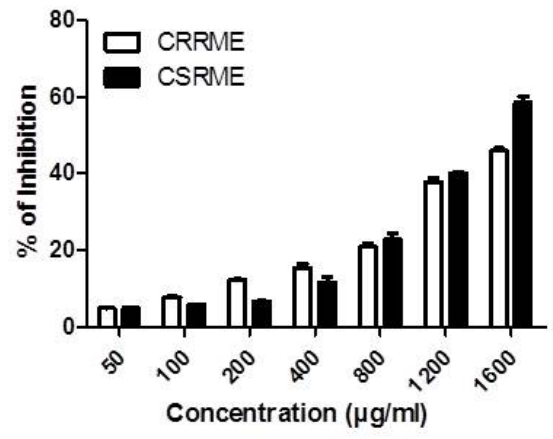

Figure 9: The total antioxidant activity (a) Ascorbic acid $[\mu \mathrm{g} / \mathrm{mL}]$ (b) Comparison of CSRME and CRRME nanoparticles [ $\mu$ g/mL]. BSA denaturation (c) Percentage of inhibition of standard Diclofenac sodium (d) Comparative Inhibition of BSA denaturation using CSRME and CRRME nanoparticles [ $\mu \mathrm{g} / \mathrm{mL}$ ]. 
Antioxidant and anti-inflammatory activity of CSRME and CRRME loaded nanoparticles

DPPH is a stable free radical at room temperature and its reduction capability to accept an electron or a hydrogen radical from antioxidants is determined by measuring the decrease in its absorbance values at $517 \mathrm{~nm}$. The DPPH assay is one of the most widely used methods for screening the antioxidant activity of plant compounds. Our results showed that the DPPH free radical scavenging activity of chitosan encapsulated C. scariosus and C. rotundus nanoparticles increases in a dose dependent manner at a concentration of $50 \mu \mathrm{g} / \mathrm{ml}$ to $2 \mathrm{mg} / \mathrm{ml}$. The free radical scavenging activity at $50 \mu \mathrm{g} / \mathrm{ml}$ is similar to that of ascorbic acid at $40 \mu \mathrm{g} / \mathrm{ml}$ and the radical scavenging activity of $C$. rotundus nanoparticles at $50 \mu \mathrm{g} / \mathrm{ml}$ is similar to $60 \mu \mathrm{g} / \mathrm{ml}$ of standard ascorbic acid (Figure 9a \& b). These results suggest that both C. scariosus and C. rotundus exhibit strong antioxidant activity due to the presence of phenolic compounds. As compared to C. scariosus, C. rotundus exhibits higher antioxidant activity due to the presence of more phenolic compounds. The in vitro anti-inflammatory effects of chitosan encapsulated C. scariosus and C. rotundus nanoparticles were evaluated against the denaturation of BSA. The results are summarised in Figure 9 (c \& d). The present findings demonstrated a concentration dependent inhibition of protein denaturation in C. scariosus and C. rotundus nanoparticles throughout the concentration range of $50-1600 \mu \mathrm{g} / \mathrm{ml}$. A diclofenac sodium (at the concentration range of $50-1600 \mu \mathrm{g} / \mathrm{ml}$ ) was used as the reference drug, which also exhibited concentration dependent inhibition of the protein denaturation. However, the effect of diclofenac sodium was found to be less, when compared with that of the C. scariosus and C. rotundus nanoparticles.

\section{DISCUSSION}

Cyperus scariosus $\mathrm{R} . \mathrm{Br}$ and Cyperus rotundus $\mathrm{L}$ belong to the Cyperaceae family. The taxonomists were indiscriminately classified that $C$. rotundus as C. scariosus and Vice versa. In this paper, we examined biochemical analysis based on GC-MS analysis showed that compounds such as 7-isopropenyl-1,4a-dimethyl-4,4a,5,6,7,8-hexahydro-3H-naphthalene2-one (cyperene), 2(1H) naphthalenone 3,5,6,7,8,8a hexa hydro-4-8adimethyl-6-(1-methyl ethenyl) (cyperol) and aromadendrene (isopatchoula-3, 5 diene) are unique to C. Rotundus, and so are not present in C. scariosus. The presence of these compounds suggests the medicinal importance of well-known anti-inflammatory compounds in the benzene insoluble fraction. ${ }^{19}$ On the other hand, the SEM-EDAX analysis also showed differing elemental compositions and their ratio across the species. This variation in elemental concentration further suggests that these plants are phylogenitically different and that they may exhibit different therapeutic actions as curative and preventive agents. ${ }^{20} \mathrm{To}$ identify the biologically active anti-inflammatory compounds, GC-MS derived compounds were subjected to molecule docking analysis. The results showed that several compounds form stable bond interactions with inflammatory associated proteins (PDB ID: 1PXX, COX2) (Table 4). However, $\mathrm{N}$-isopropyl ethylene diamine from $C$. rotundus forms three hydrogen bond interactions similar to diclofenac in complex with COX-2 (1 PXX). On the other hand, 2, 3, 5, 6-Tetra fluoro phenyl isothiocyanate from C. scariosus forms a stable hydrogen bond interaction with 1PXX and 2AW1, which is evident from the hybrid chemgauss 4 score $(-10.25 \mathrm{Kcal} / \mathrm{mol})$. No literature is available that explores the biological function of these compounds. In order to identify the possible biological functions, these compounds were subjected to a structure similarity search engine using ROCS. The results showed that 2, 3, 5, 6-Tetra fluoro phenyl isothiocyanate has a one ring structure and two acceptor domains $(\mathrm{N}=\mathrm{C}$ and $\mathrm{C}=\mathrm{S}$ ). This compound showed a $90 \%$ overlap with N, N-Dichloro4-methylbenzenesulfonamide, which consists of one central ring structure and two acceptor domains ( $S=0$ and $S=0$ ). Taken together, our results suggest that GC-MS profiles of both species are different. The major focus in drug discovery research is the designing of a better delivery system with minimal side effects. One such system is known as nanomediated drug delivery. In order to validate the therapeutic potency of the CSRME and CRRME extracts, the extracts were encapsulated using chitosan nanoparticles. The morphology of the nanoparticles was observed using a scanning electron microscope. SEM images identified that CSRME-loaded nanoparticles appeared largely spherical in shape as compared to blank nanoparticles. On the other hand, CRRME-loaded nanoparticles showed an aggregation, which may be due to the strong interaction of compounds with the nanoparticles. Encapsulation efficiency and interaction of the compounds with nanoparticles was further confirmed by phenolic assay and FT-IR analysis. The therapeutic nature of the nanoparticles was verified by measuring the antioxidant and antiinflammatory activity. The DPPH scavenging activity and denaturation of tissue proteins are well-studied in terms of the causes of inflammatory disease. ${ }^{21}$ Both CSRME and CRRME encapsulated chitosan nanoparticles positively inhibited the level of scavenging activity and the denaturation of proteins with respect to the concentrations as compared to ascorbic acid and diclofenac sodium salt respectively.

\section{CONCLUSION}

Cyperus scariosus $\mathrm{R} . \mathrm{Br}$ and Cyperus rotundus $\mathrm{L}$ belong to the Cyperaceae family. Their biochemical attributes clearly demonstrate that these two plants exhibit different compositions of trace elements and therapeutic compounds. Moreover, the hydrogen bond interaction pattern of their secondary metabolites with anti-inflammatory protein COX-2 and their ability to encapsulate into chitosan particles are also different. Finally, we conclude that these two plants hold similar therapeutic potentials, but are morphologically different.

\section{ACKNOWLEDGMENTS}

Authors would like to thank the management of KLEF University for providing facilities and Satyabama University, Chennai for conducting the SEM- EDAX analysis facilities. One of the authors, Lavanya Kakarla is thankful to DST, New Delhi for financial support under Women scientist (WOS-A) scheme.

\section{FINANCIAL SUPPORT AND SPONSORSHIP}

This work was financially supported by Department of Science and Technology, New Delhi, India, under the Women Scientist (WOS-A) project grant (SR/WOS-A/LS-1160/2014 (G).

\section{CONFLICTS OF INTEREST}

There are no conflicts of interest.

\section{REFERENCES}

\footnotetext{
1. Rajkumar V, Guha G, Kumar RA. Isolation and bioactivity evaluation of two metabolites from the methanolic extract of Oroxylum indicum stem bark. Asian Pacific Journal of Trophical Biomedicine. 2012;2(1):7-11. http://dx.doi. org/10.1016/S2221-1691(12)60120-8.

2. Rathish N, Sumitra VC. Antibacterial activities of some medicinal plants of the western region of India. Turkish Journal of Biology. 2007;31(4):231-6.

3. Nadro MS, Onoagbe IO. Effects of the aqueous and ethanolic extracts of Cassia italica leaf in normal rats. American Journal of Research Communication. 2014;2:72-80.

4. Roy P, Abdulsalam FI, Pandey DK. Evaluation of antioxidant, antibacterial, and antidiabetic potential of two traditional medicinal plants of India: Swertia cordata and Swertia chirayita. Pharmacognosy Research. 2015;7(suppl 1):57-62. http:// dx.doi.org/10.4103/0974-8490.157997; PMid:26109789 PMCid:PMC4466770.

5. Dahanukar S, Kulkarni R, Rege N. Pharmacology of medicinal plants and natural products. Ind J Pharmacol 2000;32(4):81-118.
} 
6. Cragg GM, Newman DJ. Natural products a continuing source of novel drug leads. Biochem Biophys Acta. 2013;1830(6):3670-95. http://dx.doi.org/10.1016/j. bbagen.2013.02.008; PMid:23428572 PMCid:PMC3672862.

7. Tewari NN. Some crude drugs: source, substitute and adulterant with special reference to KTM crude drug market. Sachitra Ayurveda. 1991;44(4):284-90.

8. Nirmal kumar N, Dwivedi KN, Ram B. Adulteration and substitution of Medicinal Plant: A Burning Problem in Herbal Industry. Int J Pharm Biol Arch. 2014;5:13-18.

9. Dixit M, Mitra S, Saxena E. Natural composition for curing hepatitis-B, methods for making the same and pharmaceutical formulations thereof. Google Patents. 2005.

10. Yashvanth S, Rani SS, Rao AS, Madhavendra SS. Microscopic and micro chemical evaluation (elemental Analysis) of the medicinal herb, Lippia nodiflora (Linn.) Rich (Phyla nodiflora Linn. Green). Asian Pac J Trop Disease. 2012;2:124-9. http://dx.doi.org/10.1016/S2222-1808(12)60137-6.

11. Kakarla L, Katragadda SB, Botlagunta M. Morphological and chemo profile (LC-MS and GC-MS) comparisons of Cyperus scariosus $\mathrm{R} . \mathrm{Br}$ and Cyperus rotundus L. Pharmacogn Mag. 2015;11:439-47. http://dx.doi.org/10.4103/09731296.168975; PMid:26929579; PMCid:PMC4745215.

12. Kakarla L, Mathi P, Allu PR, Rama C, Botlagunta M. Identification of human COX-2 inhibitors from Cyperus scariosus R.Br Rhizomes. Bioinformation. 2014;10(10):637-46. http://dx.doi.org/10.6026/97320630010637; PMid:25489173 PMCid:PMC4248346.

13. Saravanabhavan SS, Bose R, Skylab S, Dharmalingam S. Fabrication of Chitosan/ TPP Nano Particles as a Carrier Towards the Treatment of Cancer. Int J Drug Deliver. 2013;5(1):35-42.

14. Grenha A, Seijo B, Remunan-Lopez C. Microencapsulated chitosan nanoparticles for lung protein delivery. Eur J Pharm Sci. 2005;25(4):427-37. http://dx.doi. org/10.1016/j.ejps.2005.04.009; PMid:15893461.

15. Ramani R, Sudini S, Boddupalli BM, Anisetti RN. Antioxidant, free radical scavenging and in vitro cytotoxic studies of ethanolic extract of Leucas indica var lavandulifolia and Leucas indica var nagalapuramiana. Asian Pac J Trop Biomed. 2012;2(3):1637-42. http://dx.doi.org/10.1016/S2221-1691(12)60468-7.

16. Chandra S, Chatterjee P, Dey P, Bhattacharya S. Evaluation of in vitro anti-inflammatory activity of coffee against the denaturation of protein. Asian Pac J Trop Biomed. 2012;2(1):178-80. http://dx.doi.org/10.1016/S2221-1691(12)60154-3.

17. Singleton VL, Orthofer R, Lamuela-Raventos R.M. Analysis of total phenols and other oxidation substrates and antioxidants by means of Folin-Ciocalteu reagent. Method enzymol. 1999;299:152-178. http://dx.doi.org/10.1016/S00766879(99)99017-1.

18. Baker HW. The Treatment of Infected Wounds with Dichloramine-T with special Reference to its Advantages over the Carrol-Dakin Method. Can Med Assoc J. 1918:8(9):805-823. PMid:20311161 PMCid:PMC1585227.

19. Puratchikody A, Devi CN, Nagalakshmi G. Wound healing activity of cyperus rotundus linn. Indian J Pharm Sci. 2006;68:97-101. http://dx.doi.org/10.4103/ 0250-474X.22976.

20. Patil UH, Gaikwad DK. Effect of varying environmental conditions on mineral status of stem bark of Anogeissus latifolia. J Pharm Res. 2012;5(2):1140-43.

21. Kumar AN, Bevara GB, Laxmikoteswramma K, Malla R. Antioxidant, cytoprotective and anti-inflammatory activities of stem bark extract of Semecarpus Anacardium. Asian J Pharm Cli Res 2013;6(1):213-9.

Cite this article: Kakarla L, Othayoth R, Botlagunta M. Comparative Biochemical Studies on Indian Sedges Cyperus scariosus R.Br and Cyperus rotundus L. Pharmacognosy Journal. 2016;8(6):598-609. 